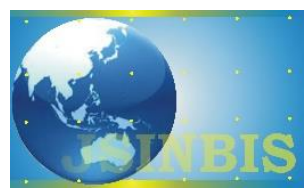

\title{
Evaluasi Tingkat Penerimaan Sistem Manajemen Aset Menggunakan Metode HOT-FIT
}

\author{
Muhammad Amiruddien ${ }^{\mathrm{a}, *}$, Aris Puji Widodo ${ }^{\mathrm{b}}$, R Rizal Isnanto ${ }^{\mathrm{c}}$ \\ ${ }^{a}$ Magister Sistem Informasi, Sekolah Pascasarjana Universitas Diponegoro \\ ${ }^{\text {b }}$ Teknik Informatika, Fakultas Sains dan Matematika Universitas Diponegoro \\ ${ }^{\mathrm{c}}$ Teknik Sistem Komputer, Fakultas Teknik Universitas Diponegoro
}

Naskah Diterima : 20 Mei 2021; Diterima Publikasi : 25 Agustus 2021

DOI: 10.21456/voll1iss2pp87-96

\begin{abstract}
The development of the institution will be directly proportional to the development of the number and types of assets it owns. The growing number and type of assets owned by an institution will have an impact on increasingly difficult management. In asset management, Diponegoro University has developed an Sistem Informasi Manajemen Aset Terpadu (SIMASET). SIMASET needs to be evaluated to find out its shortcomings and can be input for further development. This study aims to determine the factors that influence the level of acceptance and net benefits received by users from the application of SIMASET using the Human-Organization-Technology (HOT-Fit) method. This study begins with designing hypotheses, determining the sample of respondents, filling out questionnaires, and ending with questionnaire data analysis. There are 20 hypotheses tested regarding the relationship between technology, human and organizational constructs in the HOT-Fit method. The Partial Least Squares-Structural Equation Modeling (PLS-SEM) method in the Smart-PLS 3.0 application is used to analyze the questionnaire data that has been filled out by SIMASET direct users. The results showed that the net benefits of implementing SIMASET were increasing effectiveness, helping decision making, reducing errors and facilitating communication. In addition, it can be seen that SIMASET's shortcomings lie in the quality of information and service quality because they have no significant effect on system use and user satisfaction. SIMASET acceptance rate of 51.6\% or moderate taken from the $R$-square value of net benefits.
\end{abstract}

Keywords: Integrated Asset Management System; Evaluation; Acceptance Rate; PLS-SEM; HOT-Fit Method

\begin{abstract}
Abstrak
Perkembangan institusi akan berbanding lurus dengan perkembangan jumlah dan jenis aset yang dimilikinya. Semakin berkembangnya jumlah dan jenis aset yang dimiliki suatu institusi akan berdampak pada pengelolaan yang semakin sulit. Dalam pengelolaan aset yang dimilikinya, Universitas Diponegoro telah mengembangkan Sistem Informasi Manajemen Aset Terpadu (SIMASET). SIMASET perlu dilakukan evaluasi untuk diketahui kekurangan yang dimiliki dan dapat menjadi masukan untuk pengembangan selanjutnya. Penelitian ini bertujuan untuk mengetahui faktor-faktor yang mempengaruhi tingkat penerimaan dan manfaat bersih yang diterima oleh pengguna dari penerapan SIMASET dengan menggunakan metode Human-Organization-Technology (HOT-Fit). Penelitian ini diawali dengan merancang hipotesis, penentuan sampel responden, pengisian kuesioner, dan diakhiri dengan analisis data kuesioner. Terdapat 20 hipotesis yang diuji terkait hubungan antara konstruk teknologi, manusia dan organisasi pada metode HOT-Fit. Metode Partial Least Squares-Structural Equation Modeling (PLS-SEM) pada aplikasi Smart-PLS 3.0 digunakan untuk menganalisis data kuesioner yang telah diisi oleh pengguna langsung SIMASET. Hasil penelitian menunjukkan bahwa manfaat bersih yang dihasikan dari penerapan SIMASET yaitu meningkatkan efektifitas, membantu pengambilan keputusan, pengurangan kesalahan dan mempermudah komunikasi. Selain itu dapat diketahui bahwa yang menjadi kekurangan SIMASET terletak pada kualitas informasi dan kualitas layanan karena tidak berpengaruh signifikan terhadap penggunaan sistem dan kepuasan pengguna. Tingkat penerimaan SIMASET sebesar 51,6\% atau moderat diambil dari nilai $R$-square manfaat besih.
\end{abstract}

Kata kunci: Sistem Manejemen Aset Terpadu; Evaluasi; Tingkat Penerimaan; PLS-SEM; Metode HOT-Fit

\section{Pendahuluan}

Aset merupakan sumber daya bagi perseorangan atau suatu organisasi yang memilikinya, karena sebagai peralatan penunjang kegiatan dan bermanfaat untuk mencapai suatu tujuan (Dewi et al., 2018).

\footnotetext{
*) Penulis korespondensi: muh.amiruddien@gmail.com
}

Manajemen Aset didefinisikan sebagai serangkaian kegiatan yang terdiri dari mengidentifikasi aset yang dibutuhkan, merencanakan pendanaan, memperoleh aset, menyediakan sistem pendukung, pemeliharaan aset dan penghapusan atau pembaharuan aset sehingga lebih efektif dan efisien (Karnawati et al., 2020). 
Ketika sebuah perusahaan atau institusi menerapkan manajemen aset, perusahaan atau institusi tersebut dapat menjaga nilai aset, memantau penyusutan aset, menyederhanakan penganggaran, menghindari pembelian berlebih, menciptakan manajemen risiko, dan meningkatkan keamanan penyimpanan aset.

Perguruan tinggi sebagai salah satu contoh institusi yang terus mengalami perkembangan. Perkembangan Perguruan tinggi akan berbanding lurus dengan perkembangan jumlah dan jenis aset yang dimilikinya. Semakin berkembangnya jumlah dan jenis aset yang dimiliki suatu institusi akan berdampak pada pengelolaan yang semakin sulit. Perguruan tinggi dituntut untuk mempunyai sistem manajemen aset sendiri guna mempermudah dalam mengelola aset yang dimilikinya. Perkembangan teknologi informasi yang sangat pesat juga membantu dan sangat berpengaruh pada proses pengelolaan aset. Banyak institusi yang telah menggunakan sistem pengelolaan aset berbasis perangkat lunak dan online seperti Universitas Diponegoro dimana sistem tersebut dinamakan Sistem Informasi Manajemen Aset Terpadu (SIMASET).

Sistem manajemen aset berbasis perangkat lunak harus mampu mengadaptasi aturan dan budaya institusi agar dapat diterima dengan baik. Sebuah kerangka evaluasi yang bernama Human Organization Technology (HOT)-FIT dikembangkan untuk menjelaskan faktor-faktor yang mempengaruhi tingkat penerimaan dan manfaat bersih yang diperoleh atas penerapan Sistem Informasi. Metode HOT-FIT pada awalnya dikembangkan untuk pengujian Sistem Informasi Kesehatan (Yusof et al., 2008). Seiring berjalan waktu, para peneliti juga mengembangkan metode HOT-FIT untuk mengevaluasi Sistem Rekam Medis Elektronik (Erlirianto et al., 2015), Sistem Informasi Manajemen Obat (Soraya et al., 2019), Sistem Manajemen Barang Milik Daerah (Erimalata, 2016), Sistem Pengisian KRS Terkomputerisasi (Ayuardini et al., 2019), Sistem Informasi Perpustakaan (Dalimunthe \& Azhari, 2019), dan lainlain. Metode HOT-FIT mempelajari hubungan yang mungkin terjadi antara konstruk manusia, organisasi dan teknologi. Pada konstruk teknologi, ada tiga variabel yaitu kualitas sistem, kualitas informasi, dan kualitas layanan. Pada konstruk manusia, ada dua variabel yaitu penggunaan sistem, dan kepuasan pengguna. Pada konstruk organisasi, ada dua variabel yaitu struktur organisasi, dan lingkungan organisasi. Variabel-variabel tersebut yang nantinya digunakan untuk mengetahui apa saja yang mempengaruhi tingkat penerimaan sistem informasi, manfaat bersih yang ditimbulkan, dan berapa persen tingkat penerimaan sistem informasi (Yusof et al., 2006).

Penelitian ini bertujuan untuk mengetahui faktorfaktor yang mempengaruhi tingkat penerimaan, manfaat bersih yang ditimbulkan dan berapa persen tingkat penerimaan dari penerapan Sistem Manajemen Aset pada salah satu Perguruan Tinggi di Semarang.
Konstruk-konstruk yang terdapat pada metode Human Organization Technology (HOT)-FIT dikembangkan untuk menyusun hipotesis dan bahan evaluasi yang berupa kuesioner. Hasil kuesioner kemudian dianalisis menggunakan aplikasi Smart-PLS untuk mengetahui hubungan-hubungan yang mungkin terjadi dari setiap variabel pada metode HOT-FIT sehingga tujuan penelitian dapat tercapai.

\section{Kerangka Teori}

\subsection{Sistem Informasi Manajemen Aset Terpadu (SIMASET)}

Sistem Informasi Manajemen Aset Terpadu (SIMASET) Universitas Diponegoro adalah aplikasi sistem informasi terintegrasi yang digunakan untuk mengelola aset yang dimiliki Universitas Diponegoro yang prosesnya dimulai dari tahap perencanaan kebutuhan, perencanaan pemilihan penyedia, pelaksanaan pengadaan sampai dengan pengendalian kontrak, pembayaran, pencatatan aset dan penghapusan aset. Tampilan halaman utama aplikasi SIMASET dapat ditunjukkan pada Gambar 1.

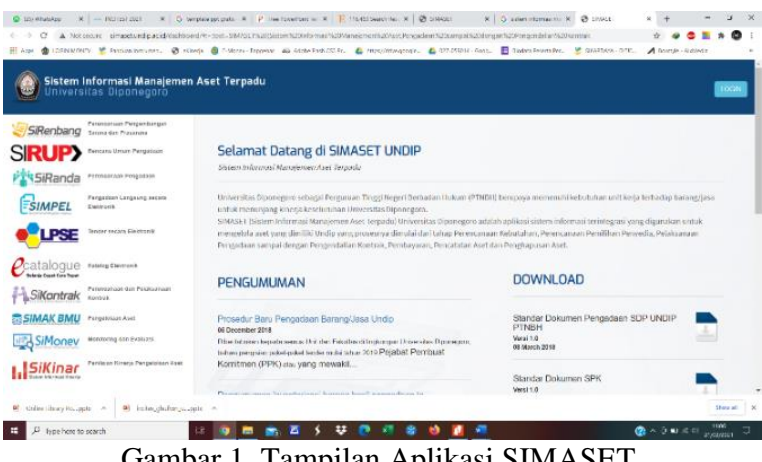

Gambar 1. Tampilan Aplikasi SIMASET

Aplikasi-aplikasi pada SIMASET merupakan gabungan dari aplikasi milik pemerintah pusat dan aplikasi yang dikembangkan sendiri oleh Universitas Diponegoro. Aplikasi yang dikembangkan sendiri oleh Universitas Diponegoro diantaranya SIRENBANG (Sistem Informasi Rencana Pengembangan), SIRANDA (Sistem Informasi Perencanaan Pengadaan), SIMPEL (Sistem Informasi Pengadaan Langsung), SIKONTRAK (Sistem Informasi Kontrak), SIMAK BMU (Sistem Informasi Manajemen Aset dan Keuangan Barang Milik UNDIP), SIMONEV (Sistem Informasi Monitoring dan Evaluasi Aset), dan SIKINAR (Sistem Informasi Kinerja Pengelolaan Aset) sedangkan aplikasi milik pemerintah pusat diantaranya SIRUP (Sistem Informasi Rencana Umum Pengadaan), LPSE (Sistem Layanan Pengadaan Secara Elektronik), dan ECATALOGUE (Katalog Elektronik). Alur proses pengadaan aset pada aplikasi SIMASET dapat dilihat pada Gambar 2. 


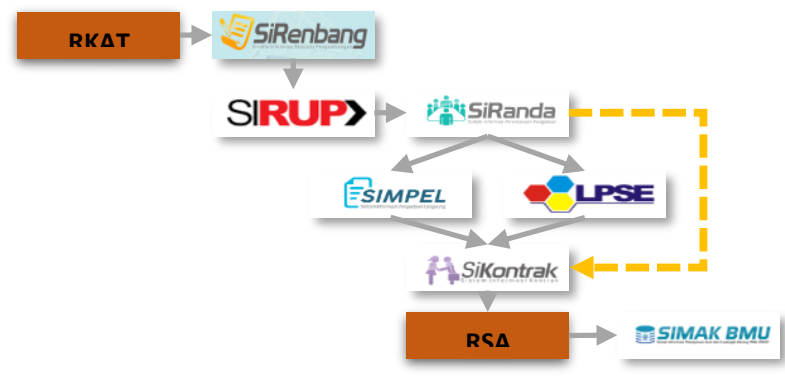

Gambar 2. Alur proses pengadaan aset pada SIMASET

Alur proses pengadaan aset dimulai dari usulan paket pengadaan yang dimasukkan dalam Rencana Kerja Anggaran Tahunan (RKAT). Data pada RKAT terhubung langsung dengan SIRENBANG. Di dalam SIRENBANG, operator melakukan pengisian data teknis pengadaan seperti tanggal pelaksanaan, jenis pengadaan, dll. Operator juga diminta mengunggah draf Kerangka Acuan Kerja (KAK), draf Harga Perkiraan Sendiri (HPS), data spesifikasi, dokumen RKAT, gambar aset, dll. Usulan pengadaan pada SIRENBANG kemudian disetujui oleh Bendahara Pengeluaran Pembantu (BPP) dan Direktur Aset dan Pengembangan.

Paket pengadaan yang telah mendapatkan persetujuan di SIRENBANG secara otomatis akan muncul di SIRUP. Persetujuan paket pengadaan di SIRUP dilakukan oleh BPP, Direktur Aset dan Pengembangan dan Rektor. Paket pengadaan yang telah mendapatkan persetujuan di SIRUP secara otomatis akan muncul di SIRANDA. Data yang ditarik dari SIRUP yaitu ID paket, nama kegiatan, sumber dana, tahun, pagu anggaran, spesifikasi, HPS, draf kontrak, dll. Pada SIRANDA, operator mengisi data pelaksanaan pengadaan dan data pelaksanaan pekerjaan. Operator mengunggah kembali data HPS, draf kontrak dan spesifikasi yang telah diperbaharui. Pada proses ini, ditentukan Tim Teknis, Kelompok Kerja (POKJA), Pejabat Pengadaan, Pejabat Penerima dan Panitia Pemeriksa Hasil Pekerjaan (PPHP). Pada akhir proses di SIRANDA akan ditentukan metode pemilihan penyedia langsung atau tender. Apabila pengadaan langsung, maka proses berikutnya akan dilakukan menggunakan SIMPEL sedangkan tender akan menggunakan LPSE.

Pada aplikasi SIMPEL, dimasukkan HPS final, jangka waktu pelaksanaan, dll. Pejabat Pengadaan akan memilih 3 (tiga) kandidat calon penyedia dan secara otomatis akan mengirimkan undangan untuk melakukan penawaran. Penyedia memasukkan penawaran dan dilakukan proses negosiasi secara daring yang berisi harga penawaran, harga pagu, harga negosiasi penyedia, harga negosiasi pejabat. Kesepakatan terjadi apabila harga negosiasi penyedia sama dengan harga negosiasi pejabat. Pada aplikasi SIKONTRAK, data umum tentang paket pengadaan ditarik dari SIRANDA. Data teknis pengadaan dimasukkan secara manual berdasarkan hasil pemilihan penyedia melalui SIMPEL dan LPSE. Operator memasukkan nama penyedia, alamat penyedia, referensi bank, nilai kontrak, NPWP, dll. Terdapat 3 (tiga) tahapan pada SIKONTRAK yaitu menyusun dokumen kontrak, pembaruan pelaksanaan kontrak, dan pembaruan pembayaran. Pada pembaruan pembayaran dipilih paket pengadaan yang berisi kode anggaran pada aplikasi Realisasi Anggaran (RSA), memasukkan Dokumen Pelaksanaan Anggaran (DPA) berupa data kontrak di RSA, dan mengunggah Berita Acara Pemeriksaan (BAP), Berita Acara Serah Terima (BAST), denda dan jenis pembayaran (termin/lunas). Data pada RSA kemudian ditarik ke SIMAK BMU berupa nomor kuitansi, nama kegiatan dan nilai kuitansi.

\subsection{Metode Human Organization Technology (HOT)- FIT}

Kerangka kerja yang menggabungkan konsep DeLone and McLean IS Success Model dan MIT90s IT-Organizational Fit model dikembangkan dan diberi nama Human Organization Technology (HOT)FIT. Penerapan metode HOT-FIT pertama kali digunakan untuk mengevaluasi Sistem Informasi Kesehatan (SIK) yang berfokus pada penerapan teknologi Fundus Imaging Systems pada sebuah rumah sakit di Inggris. Kerangka evaluasi SIK harus mempertimbangkan manusia dan organisasi. Selain itu, SIK juga perlu didukung dan dilengkapi dengan teknologi. Organisasi di sektor kesehatan harus memiliki kemampuan untuk mempersiapkan pekerja atau staf untuk beradaptasi dengan teknologi baru atau perubahan yang mungkin terjadi (Yusof et al., 2006). HOT-FIT memiliki tiga konstruk penting dan variabel yang berbeda-beda disetiap konstruk. Dalam konstruk teknologi, ada tiga variabel : kualitas sistem, kualitas informasi, dan kualitas layanan. Dalam konstruk manusia, ada dua variabel : penggunaan sistem, dan kepuasan pengguna. Dalam konstruk organisasi, ada dua variabel : struktur, dan lingkungan. Variabelvariabel tersebut digunakan untuk mengukur manfaat bersih (Yusof et al., 2006). Kerangka HOT-FIT dapat dilihat pada Gambar 3.

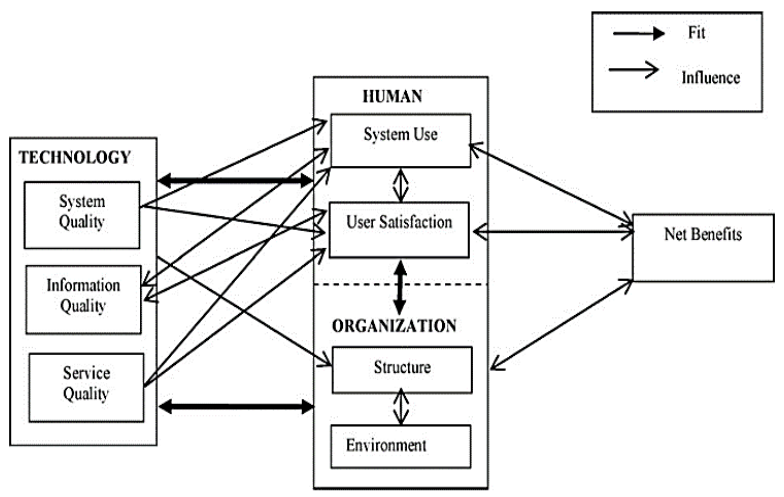

Gambar 3. Kerangka HOT-FIT (Yusof et al., 2008)

Konstruk manusia menilai sistem informasi dari variabel penggunaan sistem dan kepuasan pengguna. 
Penggunaan sistem berhubungan dengan jumlah atau durasi : (jumlah pertanyaan, jumlah waktu koneksi, jumlah fungsi yang digunakan, jumlah catatan yang diakses, frekuensi akses, frekuensi permintaan laporan, jumlah laporan yang dihasilkan), penggunaan (penggunaan langsung versus perantara), penggunaan aktual atau yang dilaporkan, sifat penggunaan (penggunaan untuk tujuan yang dimaksudkan, penggunaan yang tepat, jenis informasi yang digunakan), tujuan penggunaan, tingkat penggunaan (umum atau spesifik), penggunaan berulang, penerimaan laporan, persentase digunakan, penggunaan sukarela, motivasi untuk menggunakan, sikap, harapan atau keyakinan, pengetahuan atau keahlian, penerimaan, penolakan atau keengganan, dan pelatihan. Kepuasan pengguna berhubungan dengan kepuasan dengan fungsi spesifik, kepuasan keseluruhan, manfaat yang dirasakan, kenikmatan, kepuasan perangkat lunak, dan kepuasan pengambilan keputusan (Yusof et al., 2008).

Konstruk organisasi menilai sistem informasi dari variabel struktur organisasi dan lingkungan organisasi. Struktur organisasi berhubungan dengan sifat (jenis, ukuran), budaya, perencanaan, strategi, manajemen, proses, otonomi, komunikasi, kepemimpinan, dukungan manajemen puncak, sponsor, juara, mediator, dan kerja tim. Sedangkan lingkungan organisasi berhubungan dengan sumber pendanaan, pemerintah, politik, lokalisasi, persaingan, hubungan antar organisasi, populasi yang terpelihara, komunikasi eksternal (Yusof et al., 2008).

Konstruk teknologi terdiri dari variabel kualitas sistem, kualitas informasi, dan kualitas layanan. Kualitas sistem berfokus pada akurasi data, data currency, konten basis data, kemudahan penggunaan, kemudahan dipelajari, ketersediaan, kegunaan dari fitur sistem dan fungsi, fleksibilitas, kehandalan, teknis dukungan, keamanan, efisiensi, pemanfaatan sumber daya, waktu respon, dan waktu penyelesaian. Kualitas informasi berfokus pada seberapa pentingnya sistem, relevansi, kegunaan, keterbacaan, format, ketepatan, keringkasan isi, kelengkapan, kehandalan, ketepatan waktu, dan metode entri data. Sedangkan kualitas layanan berfokus pada kecepatan respon, jaminan, empati, kesesuaian layanan dan dukungan teknis (Yusof et al., 2008).

\subsection{Partial Least Square-Structural Equation Modeling (PLS-SEM)}

Structural Equation Modeling (SEM) merupakan metode analisis multivariat yang dapat digunakan untuk menggambarkan keterkaitan hubungan linear secara simultan antara variabel pengamatan (indikator) yang sekaligus melibatkan variabel laten. Variabel laten merupakan variabel tak teramati (unobserved) atau tidak dapat diukur (unmeasured) secara langsung, melainkan harus diukur melalui beberapa indikator. Terdapat dua tipe variabel laten dalam SEM yaitu eksogen dan endogen. Variabel laten eksogen merupakan variabel laten yang memberikan efek dan tidak dipengaruhi oleh variabel laten lainnya. Sedangkan variabel laten endogen merupakan variabel laten yang dijelaskan atau dipengaruhi oleh variabel laten eksogen. Variabel laten endogen adalah efek dari variabel laten eksogen (Ghozali \& Latan, 2015).

PLS pada awalnya diberi nama NIPALS (Nonlinear Iterative Partial Least Squares) juga dapat disebut sebagai teknik prediction-oriented. PLS pertama kali dikembangkan oleh Herman O. A. Wold dalam bidang ekonometrik pada tahun 1960-an. Pada dasarnya Wold mengembangkan PLS untuk menguji teori yang lemah dan data yang lemah seperti sampel yang kecil atau adanya masalah normalitas data. PLS tidak hanya dapat digunakan untuk menjelaskan ada tidaknya hubungan antar variabel laten (prediksi), namun PLS juga dapat digunakan untuk mengkonfirmasi teori. PLS-SEM memiliki dua model evaluasi, yaitu :

1. Model Pengukuran (Outer Model)

Model pengukuran atau Outer Model adalah model yang mendefinisikan hubungan antara variabel laten dengan setiap blok indikatornya. Evaluasi model pengukuran yang bersifat reflektif dievaluasi melalui validitas konstruk (validitas konvergen, validitas diskriminan) dan reliabilitas, sedangkan model formatif mengabaikan konsep reliabilitas dan validitas konstruk. Contoh model pengukuran dapat dilihat pada Gambar 4.

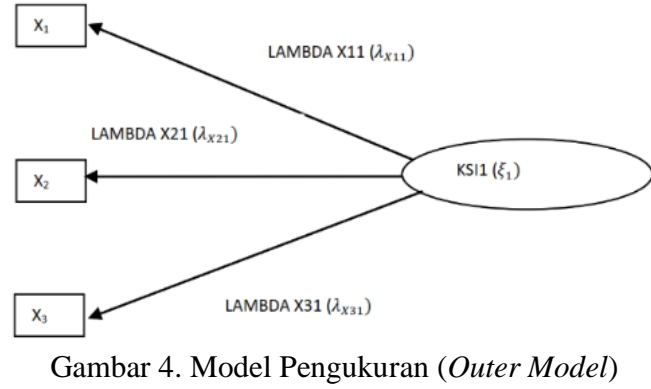

Adapun notasi matematika dari model pengukuran pada Gambar 4 dapat ditulis pada persamaan (1), (2) dan (3) seperti berikut :

$$
\begin{aligned}
& X_{1}=\lambda_{x 11} \xi_{1} \\
& X_{2}=\lambda_{x 21} \\
& X_{3}=\lambda_{x 31} \xi_{1}
\end{aligned}
$$

Keterangan :

$$
\begin{aligned}
X= & \text { indikator variabel endogen } \\
\lambda= & \text { hubungan antara variabel laten eksogen } \\
& \text { ataupun endogen terhadap indikator- } \\
& \text { indikatornya } \\
\xi= & \text { variabel laten eksogen. }
\end{aligned}
$$

\section{Model Struktural (Inner Model)}

Model struktural atau Inner Model adalah model yang menunjukkan hubungan prediksi (estimasi) antar variabel laten dalam model penelitian. Evaluasi model struktural bertujuan untuk melihat signifikansi 
hubungan antar variabel laten dalam model penelitian dengan melihat koefisien jalur. Model struktural dikatakan baik apabila memiliki satu solusi untuk satu estimasi parameter. Contoh model struktural dapat dilihat pada Gambar 5.

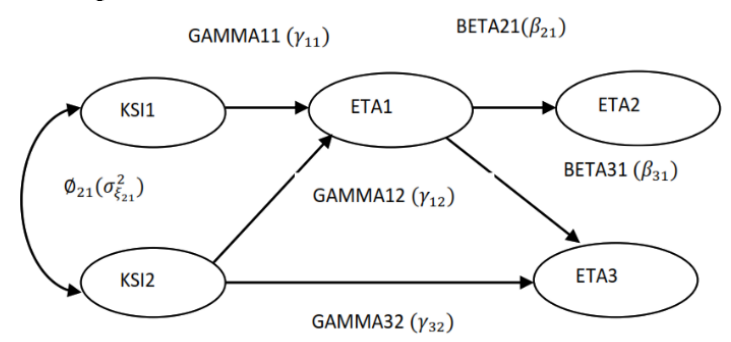

Gambar 5. Model Struktural (Inner Model)

Adapun notasi matematika dari model struktural pada Gambar 5 dapat ditulis pada persamaan (4), (5) dan (6) seperti berikut :

$$
\begin{aligned}
& \eta_{1}=\gamma_{11} \xi_{1}+\gamma_{12} \xi_{2} \\
& \eta_{2}=\beta_{21} \eta_{1} \\
& \eta_{3}=\beta_{31} \eta_{1}+\gamma_{32} \xi_{2}
\end{aligned}
$$

Keterangan :

$\eta=$ variabel laten endogen (variabel dependen)

$\gamma=$ hubungan langsung variabel eksogen terhadap variabel endogen,

$\xi=$ variabel laten eksogen (variabel independen),

$\beta=$ hubungan langsung antar variabel endogen.

Tahapan analisis PLS-SEM dijabarkan sebagai berikut (Yamin \& Kurniawan, 2009) :

1. Merancang model struktural (inner model) tujuannya untuk memformulasikan model hubungan antar variabel laten.

2. Mendefinisikan model pengukuran (outer model), tujuannya untuk mendefinisikan dan menspesifikkan hubungan antara konstruk (variabel laten) dengan indikatornya, apakah hubungannya bersifat reflektif atau formatif.

3. Membuat diagram jalur, tujuannya untuk memvisualisasikan hubungan antara indikator dengan variabel latennya serta antar variabel laten dalam model penelitian, sehingga mempermudah peneliti untuk melihat model secara keseluruhan.

4. Mengkonversikan diagram jalur dalam rumus persamaan.

5. Evaluasi model dimana terdiri dari tahapan evaluasi model pengukuran, evaluasi model struktural, dan evaluasi model gabungan.

6. Interpretasi model dimana berdasarkan kepada hasil analisis dari model penelitian (signifikansi hubungan antar variabel).

Validitas diskriminan berhubungan dengan prinsip bahwa pengukur-pengukur (variabel manifest) konstruk yang berbeda seharusnya tidak berkorelasi tinggi. Cara untuk menguji validitas diskriminan dengan indikator refleksif yaitu dengan melihat nilai cross loading untuk setiap variabel harus $>0,70$. Cara lain yang dapat digunakan untuk menguji validitas diskriminan adalah dengan membandingkan akar kuadrat dari $A V E$ untuk setiap konstruk dengan nilai korelasi antar konstruk dalam model. Validitas diskriminan yang baik ditunjukkan dari akar kuadrat $A V E$ untuk tiap konstruk lebih besar dari korelasi antar konstruk dalam model. Berikut ini rumus untuk menghitung $A V E$ ditunjukkan pada persamaan (7) sebagai berikut :

$$
A V E=\frac{\left(\sum_{i=1}^{k} \lambda_{i}^{2}\right)}{\left(\sum_{i=1}^{k} \lambda_{i}^{2}\right)+\sum_{i=1}^{k}\left(1-\lambda_{i}^{2}\right)}
$$

Keterangan :

$\lambda_{i}^{2}=$ loading factor pada pengukuran ke-i

Nilai $A V E$ direkomendasikan harus lebih besar dari 0,50 mempunyai arti bahwa $50 \%$ atau lebih varians dari indikator dapat dijelaskan. Selain uji validitas, pengukuran model juga dilakukan untuk menguji reliabilitas suatu konstruk. Uji reliabilitas dilakukan untuk membuktikan akurasi, konsistensi dan ketepatan instrumen dalam mengukur konstruk. Untuk mengukur reliabilitas suatu konstruk dengan indikator refleksif dapat dilakukan dengan dua cara yaitu dengan cronbachs alpha dan composite reliability yang sering disebut Dillon-Goldstein's. Composite Reliability dapat dihitung dengan menggunakan rumus yang dikembangkan oleh Werts untuk mengukur internal consistency ditunjukkan pada persamaan (8) sebagai berikut:

$$
C R=\frac{\left(\sum \lambda_{i}\right)^{2} \operatorname{var} F}{\left(\sum \lambda_{i}\right)^{2} \operatorname{var} F+\left(\sum \epsilon_{i}\right)}
$$

Keterangan :

$$
\begin{array}{ll}
\lambda_{-} \mathrm{i} & =\text { loading factor } \\
\operatorname{var} \mathrm{F} & =\text { factor variance } \\
\epsilon & =\text { error variance }
\end{array}
$$

Sedangkan untuk menghitung cronbach's alpha dapat dilakukan dengan persamaan (9) sebagai berikut :

$$
r_{a c}=\left[\frac{k}{k-1}\right]\left[1-\frac{\sum \sigma_{b}^{2}}{\sigma_{t}^{2}}\right]
$$

Keterangan :

$$
\begin{aligned}
& \mathrm{r} \_\mathrm{ac}=\text { koefisien reliabilitas (cronbachs alpha) } \\
& \mathrm{k}=\text { banyak butir pertanyaan } \\
& \sum{\sigma_{b}}^{2}=\text { jumlah varian per butir pertanyaan } \\
& \sigma_{t}{ }^{2}=\text { total varian }
\end{aligned}
$$

Nilai AVE dan composite reliability sebagai ukuran internal konsistensi hanya dapat digunakan untuk konstruk dengan indikator refleksif (Mode A). Ringkasan rule of thumb uji reliabilitas konstruk dengan indikator refleksif dapat dilihat pada Tabel 1. 
Tabel 1. Rule of thumb Evaluasi Model Pengukuran (Mode A) (Latan \& Ghozali, 2012)

\begin{tabular}{|c|c|c|}
\hline $\begin{array}{c}\text { Validitas dan } \\
\text { Reliabilitas }\end{array}$ & Parameter & Rule of Thumb \\
\hline \multirow[t]{3}{*}{$\begin{array}{l}\text { Validitas } \\
\text { Convergent }\end{array}$} & $\begin{array}{l}\text { Loading } \\
\text { factor }\end{array}$ & $\begin{array}{l}>0,70 \text { untuk } \\
\text { Confirmatory } \\
\text { Research } \\
>0,60 \text { untuk } \\
\text { Exploratory } \\
\text { Research }\end{array}$ \\
\hline & $\begin{array}{l}\text { Average } \\
\text { Variance } \\
\text { Extracted } \\
(A V E)\end{array}$ & $\begin{array}{l}>0,50 \text { untuk } \\
\text { Confirmatory } \\
\text { maupun Exploratory } \\
\text { Research }\end{array}$ \\
\hline & Communality & $\begin{array}{l}>0,50 \text { untuk } \\
\text { Confirmatory } \\
\text { maupun Exploratory } \\
\text { Research }\end{array}$ \\
\hline \multirow[t]{2}{*}{$\begin{array}{l}\text { Validitas } \\
\text { Diskriminan }\end{array}$} & $\begin{array}{l}\text { Cross } \\
\text { loading }\end{array}$ & $\begin{array}{l}>0,70 \text { untuk setiap } \\
\text { variabel } \\
\text { Setiap blok indikator } \\
\text { memiliki loading } \\
\text { lebih tinggi untuk } \\
\text { setiap variabel laten } \\
\text { yang diukur } \\
\text { dibandingkan dengan } \\
\text { variabel laten lainnya }\end{array}$ \\
\hline & $\begin{array}{l}\text { Akar kuadrat } \\
A V E \text { dan } \\
\text { korelasi antar } \\
\text { konstruk } \\
\text { laten }\end{array}$ & $\begin{array}{l}\text { Akar kuadrat } A V E> \\
\text { Korelasi antar } \\
\text { konstruk laten }\end{array}$ \\
\hline Reliabilitas & $\begin{array}{l}\text { Cronbachs } \\
\text { Alpha }\end{array}$ & $\begin{array}{l}>0,70 \text { untuk } \\
\text { confirmatory } \\
\text { research } \\
0,60-0,70 \text { masih } \\
\text { dapat diterima untuk } \\
\text { exploratory research }\end{array}$ \\
\hline
\end{tabular}

Untuk konstruk yang berbentuk formatif (Mode B), evaluasi model pengukuran dilakukan dengan melihat signifikansi weight. Signifikansi weight diperoleh melalui prosedur resampling (jackknifing atau bootstrapping). Uji multikolonieritas untuk konstruk formatif mutlak diperlukan dengan menghitung nilai Variance Inflation Factor (VIF) dan Tolerance. Ringkasan rule of thumb evaluasi model pengukuran (mode B) dapat dilihat pada tabel 2.

Tabel 2. Rule of thumb Evaluasi Model Pengukuran (Mode B) (Latan \& Ghozali, 2012)

\begin{tabular}{|c|c|c|c|}
\hline Kriteria & Rule of thumb & Effect Size & 0,02 kecil, 0,15 menengah dan 0,35 besar \\
\hline Significance weight & $\begin{array}{l}>1,65(\text { significance level }=10 \%) \\
>1,96(\text { significance level }=5 \%) \\
>2,58(\text { significance level }=1 \%)\end{array}$ & \multirow[t]{2}{*}{$\begin{array}{l}\text { Predictive } \\
\text { Relevance }\end{array}$} & $\begin{array}{l}>0 \text { menunjukkan model mempunyai } \\
\text { predictive relevance. } \\
<0 \text { menunjukkan model tidak mempunyai }\end{array}$ \\
\hline Multicollinearity & $\begin{array}{l}\mathrm{VIF}<10 \text { atau }<5 \\
\text { Tolerance }>0,10 \text { atau }>0,20\end{array}$ & & $\begin{array}{l}\text { predictive relevance } \\
0,02 \text { lemah, } 0,15 \text { rata-rata dan } 0,35 \text { kuat }\end{array}$ \\
\hline $\begin{array}{l}\text { Dalam me } \\
\text { nulai denga }\end{array}$ & $\mathrm{r}$ & $\begin{array}{l}\text { Significance } \\
\text { (Two-Tailed) }\end{array}$ & $\begin{array}{l}T \text {-value } 1,65(\text { significance level }=10 \%) \\
T \text {-value } 1,96(\text { significance level }=5 \%) \\
T \text {-value } 2,58(\text { significance level }=1 \%)\end{array}$ \\
\hline
\end{tabular}

interpretasi pada regresi OLS (Ordinary Least Square). Hasil dari $R$-Square mempresentasikan jumlah varians dari konstruk yang dijelaskan oleh model. Nilai $\mathrm{R}^{2}$ dapat dihitung menggunakan persamaan (10) berikut :

$$
R^{2}=\sum_{h=1}^{H} \beta_{j h} \operatorname{cor}\left(X_{j h}, Y_{j}\right)
$$

Effect size $\left(\mathrm{f}^{2}\right)$ dilakukan untuk mengetahui perubahan nilai $\mathrm{R}^{2}$ pada konstruk endogen. Perubahan nilai $\mathrm{R}^{2}$ menunjukan pengaruh konstruk eksogen terhadap konstruk endogen apakah memiliki pengaruh yang subtantif. Nilai effect size $\left(\mathrm{f}^{2}\right)$ dapat dihitung menggunakan persamaan (11) berikut :

$$
f^{2}=\frac{R_{\text {included }}^{2}-R_{\text {excluded }}^{2}}{1-R_{\text {included }}^{2}}
$$

Keterangan :

$$
\begin{aligned}
R_{\text {included }}^{2}= & \begin{array}{l}
\text { Nilai } \mathrm{R}^{2} \text { ketika konstruk eksogen } \\
\text { dimasukan ke model }
\end{array} \\
R_{\text {excluded }}^{2}= & \begin{array}{l}
\text { Nilai } \mathrm{R}^{2} \text { ketika konstruk eksogen } \\
\text { dikeluarkan dari model }
\end{array}
\end{aligned}
$$

Disamping melihat besarnya $R$-Square, evaluasi model PLS dapat juga dilakukan dengan Predictive relevance $\left(\mathrm{Q}^{2}\right)$ atau sering disebut predictive sample reuse atau dikenal dengan uji Stone Geisser. Model ini hanya cocok dilakukan pada konstruk endogen yang mempunyai indikator reflektif. Nilai relevansi prediksi jika > 0 menunjukkan konstruk laten eksogen baik sebagai variabel penjelas yang mampu memprediksi konstruk eksogennya. Nilai $\mathrm{Q}^{2}$ dapat dihitung menggunakan persamaan (12) berikut :

$$
Q^{2}=1-\frac{\sum D \cdot E_{d}}{\sum D \cdot O_{D}}
$$

Keterangan :

$\mathrm{D}=$ Omission Distance,

\begin{tabular}{|c|c|}
\hline Kriteria & Rule of thumb \\
\hline$R$-Square & $\begin{array}{l}0,67 \text { menunjukkan model kuat, } 0,33 \text { model } \\
\text { rata-rata dan } 0,19 \text { model lemah } \\
0,75 \text { menunjukkan model kuat, } 0,50 \text { model } \\
\text { rata-rata dan } 0,25 \text { model lemah }\end{array}$ \\
\hline
\end{tabular}

$\mathrm{E}=$ sum of squares of prediction errors,

$\mathrm{O}=$ sum of squares of observation.

Ringkasan rule of thumb Evaluasi Struktural dapat dilihat pada tabel 3 di bawah ini :

Tabel 3. Rule of thumb Evaluasi Model Struktural (Latan \& Ghozali, 2012)

variabel laten endogen sebagai kekuatan prediksi dari model struktural. Interpretasinya sama dengan 


\section{Metode}

Bahan yang digunakan dalam penelitian ini yaitu data kuesioner berupa persepsi pengguna aplikasi Sistem Informasi Manajemen Aset (SIMASET) milik Universitas Diponegoro. Data kuesioner didapatkan dengan melakukan wawancara langsung dan pengisian kuesioner secara online melalui google form. Responden merupakan Kepala Bagian dan Operator di Bagian Umum dan Pengelolaan Aset (UPA) di setiap Fakultas yang ada di Universitas Diponegoro. Pernyataan-pernyataan yang terdapat pada kuesioner merupakan hipotesis yang disusun oleh penulis berdasarkan konstruk dan variabel pada metode evaluasi Human Organization Technology (HOT)-FIT. Responden diminta untuk menyatakan setuju atau tidak setuju terhadap hipotesis-hipotesis tersebut.

Subyek penelitian adalah Direktorat Aset, Bagian Manajemen Aset, Unit Pelayanan Pengadaan, dan Subbagian Manajemen Aset Universitas Diponegoro Semarang dengan jumlah pegawai 70 orang, 56 lakilaki dan 14 perempuan. Skala likert digunakan dengan skor maksimal bernilai 5 untuk sangat setuju dan skor minimal bernilai 1 untuk sangat tidak setuju.

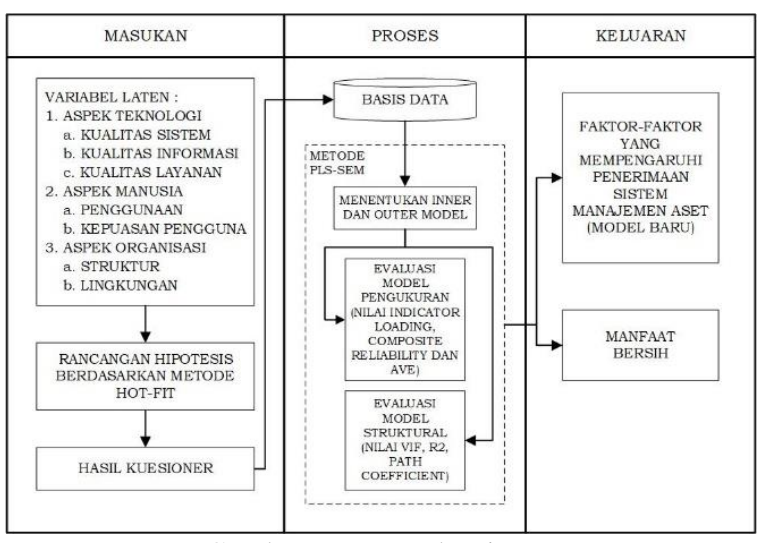

Gambar 6. Kerangka sistem

Gambar 6 merupakan kerangka sistem informasi yang menjelaskan penerapan metode HOT-FIT untuk evaluasi Sistem Manajemen Aset. Tahapan masukan yaitu menentukan konstruk dan variabel berdasarkan pada metode HOT-FIT, kemudian dibuat rancangan hipotesis dan dilakukan pengisian kuesioner oleh pengguna SIMASET. Tahapan proses atau pengolahan data yaitu menentukan inner model, outer model, menghitung evaluasi model pengukuran dan evaluasi model struktural. Tahapan terakhir atau keluaran yaitu didapatkan faktor-faktor yang mempengaruhi penerimaan Sistem Manajemen Aset dan Manfaat Bersih yang dihasilkan dengan penerapan SIMASET di Universitas Diponegoro Semarang.

\section{Hasil dan Pembahasan}

Pada penelitian ini, disusun hipotesis tentang hubungan yang mungkin terjadi antara konstruk manusia, organisasi dan teknologi pada metode HOTFIT. Terdapat 20 hipotesis yang diuji dalam penelitian ini dimana pengolahan datanya menggunakan aplikasi SmartPLS v.3 yang dikembangkan oleh Institue of Hamburg, Jerman.

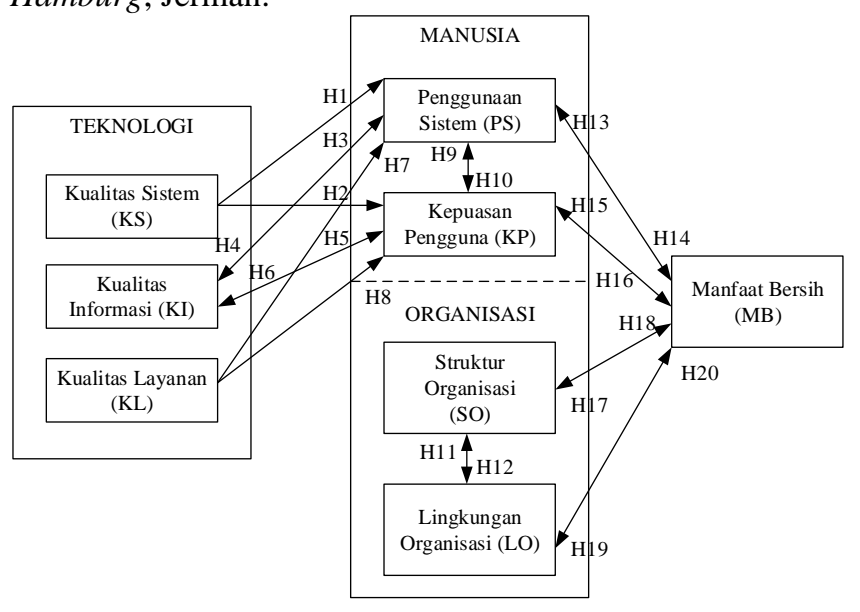

Gambar 7. Kerangka HOT-FIT (Yusof et al., 2006)

Hipotesis yang dikembangkan pada penelitian ini berdasarkan metode HOT-FIT sesuai gambar 7 adalah : (1) kualitas sistem berpengaruh positif terhadap penggunaan sistem; (2) kualitas informasi berpengaruh positif terhadap penggunaan sistem; (3) kualitas layanan berpengaruh positif terhadap penggunaan sistem; (4) kualitas sistem berpengaruh positif terhadap kepuasan pengguna; (5) kualitas informasi berpengaruh positif terhadap kepuasan pengguna; (6) kualitas layanan berpengaruh positif terhadap kepuasan pengguna; (7) penggunaan sistem berpengaruh positif terhadap kualitas informasi; (8) kepuasan pengguna berpengaruh positif terhadap kualitas informasi; (9) kepuasan pengguna berpengaruh positif terhadap penggunaan sistem; (10) penggunaan sistem berpengaruh positif terhadap kepuasan pengguna; (11) lingkungan organisasi berpengaruh positif terhadap struktur organisasi; (12) struktur organisasi berpengaruh positif terhadap lingkungan organisasi; (13) manfaat bersih berpengaruh positif terhadap penggunaan sistem; (14) penggunaan sistem berpengaruh positif terhadap manfaat bersih; (15) manfaat bersih berpengaruh positif terhadap kepuasan pengguna; (16) kepuasan pengguna berpengaruh positif terhadap manfaat bersih; (17) manfaat bersih berpengaruh positif terhadap struktur organisasi; (18) struktur organisasi berpengaruh positif terhadap manfaat bersih; (19) manfaat bersih berpengaruh positif terhadap lingkungan organisasi; (20) lingkungan organisasi berpengaruh positif terhadap manfaat bersih.

Tabel 4 menunjukkan nilai kuesioner yang digunakan untuk mengevaluasi dan mengukur tingkat penerimaan sistem manajemen aset menurut metode HOT-FIT. 
Tabel 4. Konstruksi dan Variabel Model HOT-FIT



Pada tabel 4 dapat dilihat hasil uji validasi dimana nilai loading cukup tinggi yaitu diatas 0,7 . Hal ini menunjukkan bahwa indikator tersebut memenuhi standar pengukuran validitas konvergen (Latan \& Ghozali, 2012).

Tabel 5. AVE

\begin{tabular}{|c|c|c|c|}
\hline Konstruk & Variabel & AVE & $\begin{array}{l}\text { Validitas } \\
\text { Diskriminan }\end{array}$ \\
\hline \multirow[t]{3}{*}{ Teknologi } & Kualitas Sistem (KS) & 0.789 & Baik \\
\hline & $\begin{array}{l}\text { Kualitas Informasi } \\
\text { (KI) }\end{array}$ & 1,000 & Baik \\
\hline & $\begin{array}{l}\text { Kualitas Layanan } \\
(\mathrm{KL})\end{array}$ & 0,665 & Baik \\
\hline \multirow[t]{2}{*}{ Manusia } & $\begin{array}{l}\text { Penggunaan Sistem } \\
\text { (PS) }\end{array}$ & 1,000 & Baik \\
\hline & $\begin{array}{l}\text { Kepuasan Pengguna } \\
(\mathrm{KP})\end{array}$ & 0,655 & Baik \\
\hline \multirow[t]{2}{*}{ Organisasi } & $\begin{array}{l}\text { Struktur Organisasi } \\
\text { (SO) }\end{array}$ & 0,867 & Baik \\
\hline & $\begin{array}{l}\text { Lingkungan } \\
\text { Organisasi (EO) }\end{array}$ & 0,646 & Baik \\
\hline $\begin{array}{l}\text { Manfaat } \\
\text { Bersih } \\
\text { (MB) }\end{array}$ & & 0,728 & Baik \\
\hline
\end{tabular}

Tabel 6. Komposit reliabilitas

\begin{tabular}{|c|c|c|c|c|}
\hline Konstruk & Variabel & $\begin{array}{l}\text { Cronbach's } \\
\text { Alpha }\end{array}$ & $\begin{array}{l}\text { Composite } \\
\text { Reliability }\end{array}$ & Keterangan \\
\hline \multirow[t]{3}{*}{ Teknologi } & $\begin{array}{l}\text { Kualitas } \\
\text { Sistem (KS) }\end{array}$ & 0,736 & 0,882 & $\begin{array}{l}\text { Dapat } \\
\text { diandalkan }\end{array}$ \\
\hline & $\begin{array}{l}\text { Kualitas } \\
\text { Informasi (KI) }\end{array}$ & 1,000 & 1,000 & $\begin{array}{l}\text { Dapat } \\
\text { diandalkan }\end{array}$ \\
\hline & $\begin{array}{l}\text { Kualitas } \\
\text { Layanan (KL) } \\
\end{array}$ & 0,786 & 0,855 & $\begin{array}{l}\text { Dapat } \\
\text { diandalkan }\end{array}$ \\
\hline \multirow[t]{2}{*}{ Manusia } & $\begin{array}{l}\text { Penggunaan } \\
\text { Sistem (PS) }\end{array}$ & 1,000 & 1,000 & $\begin{array}{l}\text { Dapat } \\
\text { diandalkan }\end{array}$ \\
\hline & $\begin{array}{l}\text { Kepuasan } \\
\text { Pengguna (KP) }\end{array}$ & 0,736 & 0,850 & $\begin{array}{l}\text { Dapat } \\
\text { diandalkan }\end{array}$ \\
\hline \multirow[t]{2}{*}{ Organisasi } & $\begin{array}{l}\text { Struktur } \\
\text { Organisasi } \\
\text { (SO) }\end{array}$ & 0,848 & 0,929 & $\begin{array}{l}\text { Dapat } \\
\text { diandalkan }\end{array}$ \\
\hline & $\begin{array}{l}\text { Lingkungan } \\
\text { Organisasi } \\
\text { (LO) }\end{array}$ & 0,722 & 0,845 & $\begin{array}{l}\text { Dapat } \\
\text { diandalkan }\end{array}$ \\
\hline $\begin{array}{l}\text { Manfaat } \\
\text { Bersih } \\
\text { (MB) }\end{array}$ & & 0,877 & 0,914 & $\begin{array}{l}\text { Dapat } \\
\text { diandalkan }\end{array}$ \\
\hline
\end{tabular}

Tabel 5 menunjukkan validitas diskriminan dimana nilai $A V E$ masing-masing konstruk lebih besar dari 0,5, sehingga menunjukkan validitas diskriminan yang baik. Reliabilitas yang baik juga ditunjukkan pada Tabel 6 yang menunjukkan komposit reliabilitas tinggi dan cronbachs alpha tinggi, yaitu lebih dari 0,6 .

Tabel 7. Pengujian Hipotesis

\begin{tabular}{clcccl}
\hline H & Variabel & $\begin{array}{c}\text { Path } \\
\text { Coefficient }\end{array}$ & t-value & p-value & $\begin{array}{c}\text { Hasil } \\
\text { Tes }\end{array}$ \\
\hline H1 & KS $\rightarrow$ PS & 0,464 & 3,294 & 0,001 & Diterima \\
H2 & KS $\rightarrow$ KP & 0,434 & 2,953 & 0,003 & Diterima \\
H3 & KI $\rightarrow$ PS & $-0,181$ & 1,799 & 0,072 & Ditolak \\
H4 & PS $\rightarrow$ KI & $-0,067$ & 0,473 & 0,636 & Ditolak \\
H5 & KI $\rightarrow$ KP & $-0,096$ & 0,706 & 0,480 & Ditolak \\
H6 & KP $\rightarrow$ KI & 0,108 & 0,555 & 0,579 & Ditolak \\
H7 & KL $\rightarrow$ PS & 0,046 & 0,400 & 0,689 & Ditolak \\
H8 & KL $\rightarrow$ KP & 0,147 & 0,931 & 0,352 & Ditolak \\
H9 & KP $\rightarrow$ PS & 0,261 & 2,134 & 0,033 & Diterima \\
H10 & PS $\rightarrow$ KP & 0,177 & 1,551 & 0,121 & Ditolak \\
H11 & LO $\rightarrow$ SO & 0,566 & 4,987 & 0,000 & Diterima \\
H12 & SO $\rightarrow$ LO & 0,326 & 2,841 & 0,005 & Diterima \\
H13 & MB $\rightarrow$ PS & 0,366 & 2,462 & 0,014 & Diterima \\
H14 & PS $\rightarrow$ MB & 0,225 & 2,112 & 0,035 & Diterima \\
H15 & MB $\rightarrow$ KP & 0,374 & 2,899 & 0,004 & Diterima \\
H16 & KP $\rightarrow$ MB & 0,229 & 2,131 & 0,033 & Diterima \\
H17 & MB $\rightarrow$ SO & 0,544 & 4,520 & 0,000 & Diterima \\
H18 & SO $\rightarrow$ MB & 0,228 & 2,104 & 0,035 & Diterima \\
H19 & MB $\rightarrow$ LO & 0,440 & 3,951 & 0,000 & Diterima \\
H20 & LO $\rightarrow$ MB & 0,224 & 1,937 & 0,053 & Diterima \\
\hline
\end{tabular}

Tabel 7 menunjukkan hasil uji hipotesis dimana jika nilai $t$-value melebihi nilai $t$-table maka signifikan. Tingkat signifikansi yang digunakan adalah $95 \%(\alpha=0,05)$ yaitu 1,96 (Abda'u et al., 2018). Jika nilai $t$-value melebihi 1,96 maka berpengaruh positif, sedangkan jika lebih kecil berarti tidak berpengaruh.

Tabel 8. R-Square

\begin{tabular}{lll}
\hline Konstruk & R-Square & Informasi \\
\hline Kepuasan Pengguna (KP) & 0,238 & berhasil \\
Kualitas Informasi (KI) & 0,009 & Tidak berhasil \\
Penggunaan Sistem (PS) & 0,384 & berhasil \\
Struktur Organisasi (SO) & 0,320 & berhasil \\
Lingkungan Organisasi (LO) & 0,456 & berhasil \\
Manfaat Bersih (MB) & 0,516 & berhasil \\
\hline
\end{tabular}


Tabel 8 menunjukkan evaluasi inner model untuk setiap variabel dimana kepuasan pengguna memiliki nilai $R$-square sebesar 0,238 dimana SIMASET diterima namun perlu adanya perbaikan kualitas, sedangkan penggunaan sistem memiliki nilai $R$ square sebesar 0,384 dimana SIMASET hanya digunakan oleh sedikit pengguna. Nilai $R$-square struktur organisasi dan lingkungan organisasi masingmasing bernilai 0,320 dan 0,456 menunjukkan saling mempengaruhi. Nilai $R$-square manfaat bersih sebesar 0,516 menggambarkan tingkat penerimaan SIMASET sebesar $51,6 \%$.

Hasil penelitian tentang evaluasi tingkat penerimaan Sistem Manajemen Aset ini membuktikan bahwa SIMASET cukup diterima. Dari hasil statistik menunjukkan bahwa penggunaan sistem, kepuasan pengguna, struktur organisasi dan lingkungan organisasi signifikan mempengaruhi manfaat bersih. Kepuasan pengguna mempunyai pengaruh signifikan terhadap penggunaan sistem namun penggunaan sistem tidak mempengaruhi kepuasan pengguna. Struktur organisasi dan lingkungan organisasi mempunyai hubungan yang saling mempengaruhi. Masukan kepada pengembang kedepan untuk dapat meningkatkan kualitas informasi dan kualitas layanan karena tidak berpengaruh siginifikan terhadap penggunaan sistem dan kepuasan pengguna.

\section{Kesimpulan}

Berdasarkan hasil penelitian dapat disimpulkan sebagai berikut :

1. Pada konstruk teknologi, kualitas sistem mempunyai pengaruh signifikan terhadap penggunaan sistem dan kepuasan pengguna namun kualitas informasi dan kualitas layanan tidak berpengaruh siginifikan.

2. Pada konstruk manusia, kepuasan pengguna berpengaruh signifikan terhadap penggunaan sistem namun penggunaan sistem tidak berpengaruh signifikan terhadap kepuasan pengguna.

3. Pada konstruk organisasi, struktur organisasi dan lingkungan organisasi saling berpengaruh satu sama lain.

4. Konstruk manusia dan organisasi berpengaruh signifikan terhadap manfaat bersih begitu pula sebaliknya.

5. Manfaat bersih yang diterima dan diakui pengguna langsung dari pemanfaatan SIMASET yaitu meningkatkan efektivitas, membantu pengambilan keputusan, pengurangan kesalahan dan mempermudah komunikasi.

6. Hasil penelitian membuktikan bahwa tingkat penerimaan SIMASET sebesar 51,6\% diambil dari nilai R2 manfaat bersih.

Saran untuk penelitian selanjutnya dan kepada pemangku kepentingan terkait pengembangan SIMASET kedepannya:
1. Penelitian selanjutnya agar dapat mengupas tuntas aplikasi-aplikasi yang terdapat didalam SIMASET karena SIMASET sendiri merupakan gabungan dari banyak aplikasi untuk pengelolaan aset sehingga diketahui kekurangan pada setiap aplikasi.

2. Pengembangan SIMASET selanjutnya untuk memperhatikan kualitas informasi dan kualitas layanan.

\section{Daftar Pustaka}

Abda'u, P.D., Winarno, W.W., \& Henderi, H., 2018. Evaluasi penerapan SIMRS menggunakan metode HOT-Fit di RSUD dr. Soedirman Kebumen. INTENSIF: Jurnal Ilmiah Penelitian Dan Penerapan Teknologi Sistem Informasi, 2(1), 46. https://doi.org/10.29407/intensif.v2i1.11817

Ayuardini, M., Ridwan, A., 2019. Implementasi metode Hot Fit pada evaluasi tingkat kesuksesan sistem pengisian KRS terkomputerisasi. Faktor Exacta, 12(2), 122-131. https://doi.org/10.30998/faktorexacta.v12i2.3639

Dalimunthe, N. \& Azhari, W.A., 2019. Analisa sistem informasi perpustakaan dengan pendekatan Human Organization Technology (Hot) Fit Model (Studi Kasus: Perpustakaan UIN Suska Riau). Seminar Nasional Teknologi ..., 43, 30-41. http://ejournal.uinsuska.ac.id/index.php/SNTIKI/article/view/7909

Dewi, S., Jannah, L.M., \& Jumaryadi, Y., 2018. Analisis dan perancangan sistem informasi manajemen aset tetap pada PT. Metis Teknologi Corporindo. JUST IT: Jurnal Sistem Informasi, Teknologi Informasi dan Komputer, 9(1), 81-91.

Erimalata, S., 2016. Pendekatan Hot-Fit framework dalam generalized structural component analysis pada sistem informasi manajemen barang milik daerah: sebuah pengujian efek resiprokal. Jurnal Akuntansi dan Investasi, 17(2), 141-157. https://doi.org/10.18196/jai.2016.0051.141-157

Erlirianto, L.M., Ali, A.H.N., \& Herdiyanti, A., 2015. The implementation of the Human, Organization, and Technology-Fit (HOT-Fit) framework to evaluate the Electronic Medical Record (EMR) system in a hospital. Procedia Computer Science, 72 , 580-587. https://doi.org/10.1016/j.procs.2015.12.166

Ghozali, I., \& Latan, H., 2015. Partial least squares : konsep, teknik dan aplikasi menggunakan program SmartPLS3.0 untuk penelitian empiris (Ed.2). Badan Penerbit Universitas Diponegoro Semarang.

Karnawati, H., Purnama, P.D., \& Azmi, T.U., 2020. Analisis kinerja aset destinasi wisata waduk, Studi kasus : Waduk Cijere, Kabupaten Bandung Barat. Jurnal Manajemen Aset Infrastruktur \& Fasilitas, 4(4), 299-316. https://doi.org/10.12962/j26151847.v4i4.7903 
Soraya, I., Adawiyah, W.R. \& Sutrisna, E., 2019. Pengujian model Hot Fit pada sistem informasi manajemen obat di instalasi farmasi Rsgmp Unsoed Purwokerto. Jurnal Ekonomi, Bisnis, dan Akuntansi, 21(1), 1-16. https://doi.org/10.32424/jeba.v21i1.1261

Yamin, S. dan Kurniawan, H., 2009. Statistik SPSS Complete : Teknik analisis statistik terlengkap dengan software SPSS structural equation modeling : belajar lebih mudah teknik analisis data kuesioner dengan smart-pls. Analisis korespondensi bab analisis diskriminan.
Yusof, M. M., Kuljis, J., Papazafeiropoulou, A., \& Stergioulas, L.K., 2008. An evaluation framework for health information systems : human, organization and technology-fit factors (HOT-fit). International Journal of Medical Informatics, 77(6), 386-398. https://doi.org/10.1016/j.ijmedinf.2007.08.011

Yusof, M.M., Paul, R.J., \& Stergioulas, L.K., 2006. Towards a framework for health information systems. Proceedings of the Annual Hawaii International Conference on System Sciences, 5. https://doi.org/10.1109/HICSS.2006.491 